\title{
Corrosion Inhibition of Carbon Steel in Sea Water by Glutamic Acid - $\mathbf{Z n}^{2+}$ System
}

\author{
S. GOWRI ${ }^{\mathrm{a}^{*}}$, J. SATHIYABAMA ${ }^{\mathrm{a}}$, S. RAJENDRAN ${ }^{\mathrm{a}, \mathrm{b}}$ \\ Z. ROBERT KENNEDY ${ }^{\mathrm{b}}$ and S. AGILA DEVI ${ }^{\mathrm{c}}$
}

${ }^{a}$ PG and Research Department of Chemistry, Corrosion Research Centre, GTN Arts College, Dindigul - 624 005, India

${ }^{\mathrm{b}}$ Department of Chemistry, RVS School of Engineering and Technology, Dindigul, India

${ }^{\mathrm{c}}$ Department of Chemistry Mahendra Institute of Engineering and Technology, Tiruchengode- 637503, Tamilnadu, India

brigow@yahoo.co.in

Received 26 July 2012 / Accepted 16 August 2012

Abstract: The inhibition efficiency of glutamic acid (GA) - $\mathrm{Zn}^{2+}$ system in controlling corrosion of carbon steel in sea water has been evaluated by weight loss method. The formulation consisting of $200 \mathrm{ppm}$ of glutamic acid and $25 \mathrm{ppm}$ of $\mathrm{Zn}^{2+}$ has $87 \%$ inhibition efficiency (IE). A synergistic effect exists between glutamic acid and $\mathrm{Zn}^{2+}$. Polarization study reveals that the glutamic acid $-\mathrm{Zn}^{2+}$ system function as an anodic inhibitor and the formulation controls the anodic reaction predominantly. The nature of the protective film on metal surface has been analyzed by AFM analysis.

Keywords: Corrosion, Carbon steel, Amino acid, Glutamic acid, Electro chemical techniques.

\section{Introduction}

Amino acids have the ability to control the corrosion of various metals ${ }^{1-10}$. Generally amino acids have two polar groups, namely, one amino group and one carboxyl group. It can coordinate with metals through the nitrogen atom and oxygen atom of the carboxyl group. They have used to prevent the corrosion of metals such as mild steel ${ }^{1,6,9}$, aluminum ${ }^{10}$ and copper ${ }^{3}$.

Organic compounds are recognized as effective inhibitors of the corrosion of many metal and alloys. The efficiency of an organic compound as a corrosion inhibitor is closely associated with the chemical adsorption ${ }^{11,12}$. Most of these organic compounds contain nitrogen, sulphur, oxygen and multiple bonds in the molecules which are adsorbed on the metal surface and the organic compound ${ }^{13,14}$. A survey of the available literature reveals that the corrosion inhibition by amino acids (Glycine, alanine, glatamic acid and methionine) on copper electrode in aqueous medium has been investigated ${ }^{15}$. Aouniti et al., have reported the corrosion inhibition of tryptophan as corrosion inhibitors of aromo iron in acid chloride solution $^{16}$. The present work is under taken; 
1. To evaluate the inhibition efficiency of GA $-\mathrm{Zn}^{2+}$ system in controlling corrosion of carbon steel immersed in the absence and presence of $\mathrm{Zn}^{2+}$ by weight loss method.

2. To investigate the mechanistic aspects of corrosion inhibition by electrochemical studies like polarization study.

3. To analyse the protective film AFM.

\section{Experimental}

Carbon steel specimens $[0.0267 \% \mathrm{~S}, 0.06 \% \mathrm{P}, 0.4 \% \mathrm{Mn}, 0.1 \% \mathrm{C}$ and the rest iron] of dimensions $1.0 \mathrm{~cm} \times 4.0 \mathrm{~cm} \times 0.2 \mathrm{~cm}$ were polished to a mirror finish and degreased with trichloroethylene.

\section{Weight loss method}

Carbon steel specimens were immersed in $100 \mathrm{~mL}$ of the sea water containing various concentrations of the inhibitor in the presence and absence of $\mathrm{Zn}^{2+}$ for one day. The weight of the specimens before and after immersion was determined using a Shimadzu balance, model AY62. The corrosion products were cleansed with Clarke's solution ${ }^{17}$. The inhibition efficiency (IE) was then calculated using the equation:

$$
\mathrm{IE}=100\left[1-\left(\mathrm{W}_{2} / \mathrm{W}_{1}\right)\right] \%
$$

Where $\mathrm{W}_{1}=$ corrosion rate in the absence of the inhibitor, $\mathrm{W}_{2}=$ corrosion rate in the presence of the inhibitor. Molecular structure of glutamic acid.

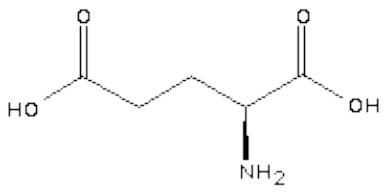

\section{Potentiodynamic polarization}

Polarization studies were carried out in a CHI- electrochemical work station with impedance model 660A. It was provided with iR compensation facility. A three electrode cell assembly was used. The working electrode was carbon steel. A SCE was the reference electrode. Platinum was the counter electrode. From polarisation study, corrosion parameters such as corrosion potential $\left(\mathrm{E}_{\text {corr }}\right)$, corrosion current $\left(\mathrm{I}_{\text {corr }}\right)$, Tafel slopes anodic $=\mathrm{b}_{\mathrm{a}}$ and cathodic $=\mathrm{b}_{\mathrm{c}}$ and LPR value. The scan rate (V/S) was 0.01 . Hold time at (Efcs) was zero and quiet time (s) was two.

\section{Surface examination study}

The carbon steel specimens were immersed in various test solutions for a period of 1 day. After 1 day, the specimens were taken out and dried. The nature of the film formed on the surface of the metal specimen was analyzed by various surface analysis techniques.

\section{Atomic Force Microscopy characterization (AFM)}

The carbon steel specimen immersed in blank and in the inhibitor solution for a period of one day was removed, rinsed with double distilled water, dried and subjected to the surface examination. Atomic force microscopy (Veeco dinnova model) was used to observe the samples' surface in tapping mode, using cantilever with linear tips. The scanning area in the images was $5 \mu \mathrm{m} \times 5 \mu \mathrm{m}$ and the scan rate was $0.6 \mathrm{HZ} /$ second. 


\section{Results and Discussion}

\section{Weight loss study}

The physicochemical parameters of sea water are given in the Table 1. The inhibition efficiencies (IE) and corrosion rates of GA in controlling of corrosion of carbon steel immersed in sea water, in the presence and absence of $\mathrm{Zn}^{2+}$ by weight loss method are given in the Table 2 .

Table 1. Physicochemical parameters of sea water (Sampling place: Ramnad, Tamilnadu, India)

\begin{tabular}{cc}
\hline Parameters & Results \\
\hline Total dissolved solid & $33490 \mathrm{ppm}$ \\
Electrical conductivity & $49250 \mathrm{mics} / \mathrm{cm}$ \\
$\mathrm{pH}$ & 8.14 \\
Total hardness as $\mathrm{CaCo}_{3}$ & $84 \mathrm{ppm}$ \\
Calcium & $16 \mathrm{ppm}$ \\
Magnesium & $11 \mathrm{ppm}$ \\
Chloride & $16200 \mathrm{ppm}$ \\
Sulphate & $2345 \mathrm{ppm}$ \\
\hline
\end{tabular}

Table 2. The corrosion inhibition efficiencies and the corresponding corrosion rates

\begin{tabular}{ccccccc}
\hline \multirow{2}{*}{$\begin{array}{c}\text { Inhibitor } \\
\text { GA, ppm }\end{array}$} & \multicolumn{7}{c}{0} & $\mathrm{Zn}^{2+}, \mathrm{ppm}$ \\
\cline { 2 - 7 } & IE, \% & CR(mdd) & IE, \% & CR(mdd) & IE, \% & CR(mdd) \\
\hline 0 & - & 27.27 & 41 & 20.91 & 64 & 12.73 \\
50 & 29 & 21.82 & 48 & 18.18 & 69 & 10.91 \\
100 & 26 & 22.73 & 53 & 16.36 & 69 & 10.91 \\
150 & 64 & 10.91 & 53 & 16.36 & 69 & 10.91 \\
200 & 35 & 20.00 & 53 & 16.36 & 87 & 04.45 \\
250 & 32 & 20.91 & 53 & 16.36 & 64 & 12.73 \\
\hline
\end{tabular}

mmd=millimeter per day

The formulation consisting of 200 ppm of GA and 25 ppm of $\mathrm{Zn}^{2+}$ shows $87 \%$ of inhibition efficiency. Weight loss study reveal that GA and $\mathrm{Zn}^{2+}$ individually showed some IE, but exhibited better IE when applied in combination. This suggests that GA and $\mathrm{Zn}^{2+}$ exhibit synergistic behavior ${ }^{18}$.

\section{Analysis of polarization curves}

Polarization study has been used to know if a protective film is formed on the metal surface. If a protective film is formed on the metal surface, the LPR value increases and corrosion current value decreases ${ }^{19-22}$. The potentiodynamic polarization curves of carbon steel immersed in various test solutions are shown in Figure 1. The corrosion parameters are given in Table 3.

Table 3. Corrosion parameters of carbon steel immersed in sea water in the presence and absence of inhibitor obtained by polarization method

\begin{tabular}{ccccccc}
\hline $\begin{array}{c}\mathrm{GA} \\
\mathrm{ppm}\end{array}$ & $\begin{array}{c}\mathrm{Zn}^{2+} \\
\mathrm{ppm}\end{array}$ & $\begin{array}{c}\mathrm{E}_{\text {corr }} \mathrm{mV} \\
\text { vs. SCE }\end{array}$ & $\begin{array}{c}\mathrm{I}_{\text {corr }} \\
\mathrm{A} / \mathrm{cm}^{2}\end{array}$ & $\begin{array}{c}\mathrm{b}_{\mathrm{a}} \\
\mathrm{mV} / \mathrm{dec}\end{array}$ & $\begin{array}{c}\mathrm{b}_{\mathrm{c}} \\
\mathrm{mV} / \mathrm{dec}\end{array}$ & $\begin{array}{c}\text { LPR ohm } \\
\mathrm{cm}^{2}\end{array}$ \\
\hline 0 & 0 & -784 & $7.042 \times 10^{-6}$ & 232 & 139 & $5.375 \times 10^{3}$ \\
200 & 25 & -768 & $6.763 \times 10^{-6}$ & 237 & 148 & $5.849 \times 10^{3}$ \\
\hline
\end{tabular}




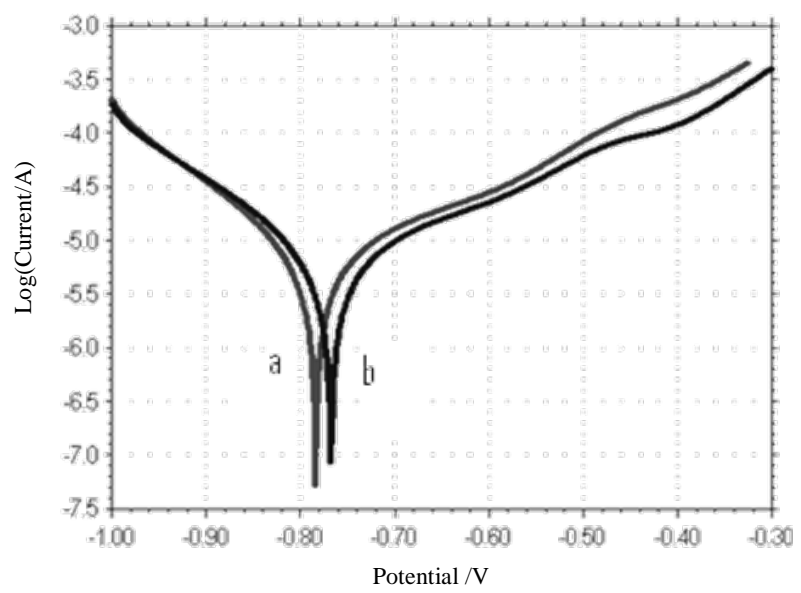

Figure 1. Polarisation curves of carbon steel immersed in various test solutions a) sea water b) sea water containing $200 \mathrm{ppm}$ of GA and $25 \mathrm{ppm}$ of $\mathrm{Zn}^{2+}$

When the carbon steel is immersed in sea water the corrosion potential $\left(\mathrm{E}_{\text {corr }}\right)$ is $784 \mathrm{mV}$ vs. SCE and the corrosion current $\left(\mathrm{I}_{\text {corr }}\right)$ is $7.042 \times 10^{-6} \mathrm{~A} / \mathrm{cm}^{2}$. When $200 \mathrm{ppm}$ of GA and $25 \mathrm{ppm}$ of $\mathrm{Zn}^{2+}$ are added to the sea water, the corrosion potential shifted to the anodic side $-768 \mathrm{mV} v$ s. SCE. The corrosion current is $6.763 \times 10^{-6} \mathrm{~A} / \mathrm{cm}^{2}$. The linear polarization resistance has increased from $5.375 \times 10^{3} \Omega \mathrm{cm}^{2}$ to $5.849 \times 10^{3} \Omega \mathrm{cm}^{2}$. This suggests that a protective film is formed on the metal surface. The $\mathrm{GA}-\mathrm{Zn}^{2+}$ system functions as anodic inhibitor, since the corrosion potential shifted to anodic side ${ }^{23-27}$.

\section{Atomic force microscopy characterization}

Atomic force microscopy (AFM) or scanning force microscopy (SFM) is a very highresolution type of scanning probe microscopy, with demonstrated resolution on the order of fractions of a nanometer, more than 1000 times better than the optical diffraction limit ${ }^{28}$. The three dimensional (3D) AFM morphologies and the AFM cross-sectional profile for polished carbon steel surface (reference sample), carbon steel surface immersed in sea water (blank sample) and carbon steel surface immersed in sea water containing the formulation of 200 ppm of GA and 25 ppm of $\mathrm{Zn}^{2+}$ are shown as Figure 2. Images (a, d,), (b, e,), (c, f,) respectively.

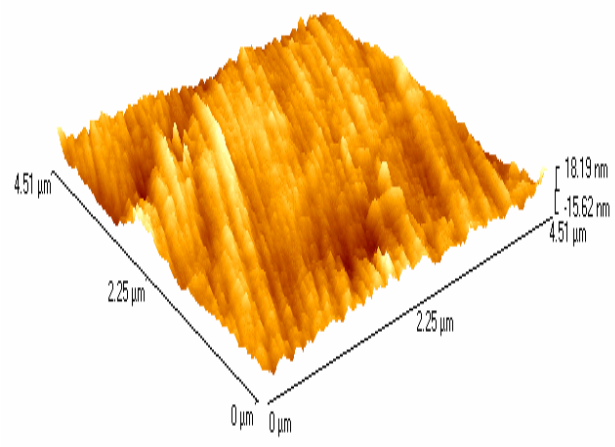

a

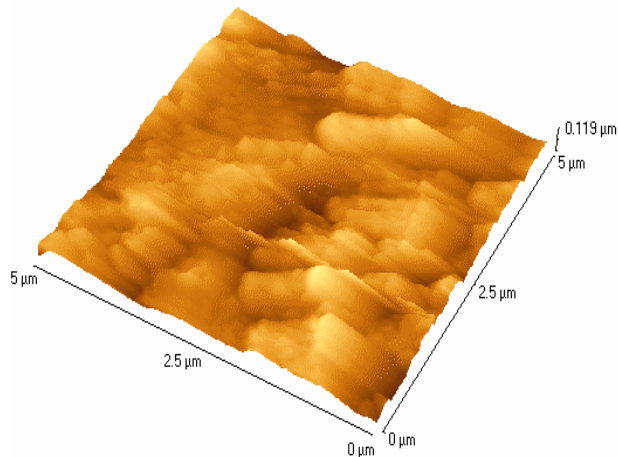

$\mathrm{b}$ 

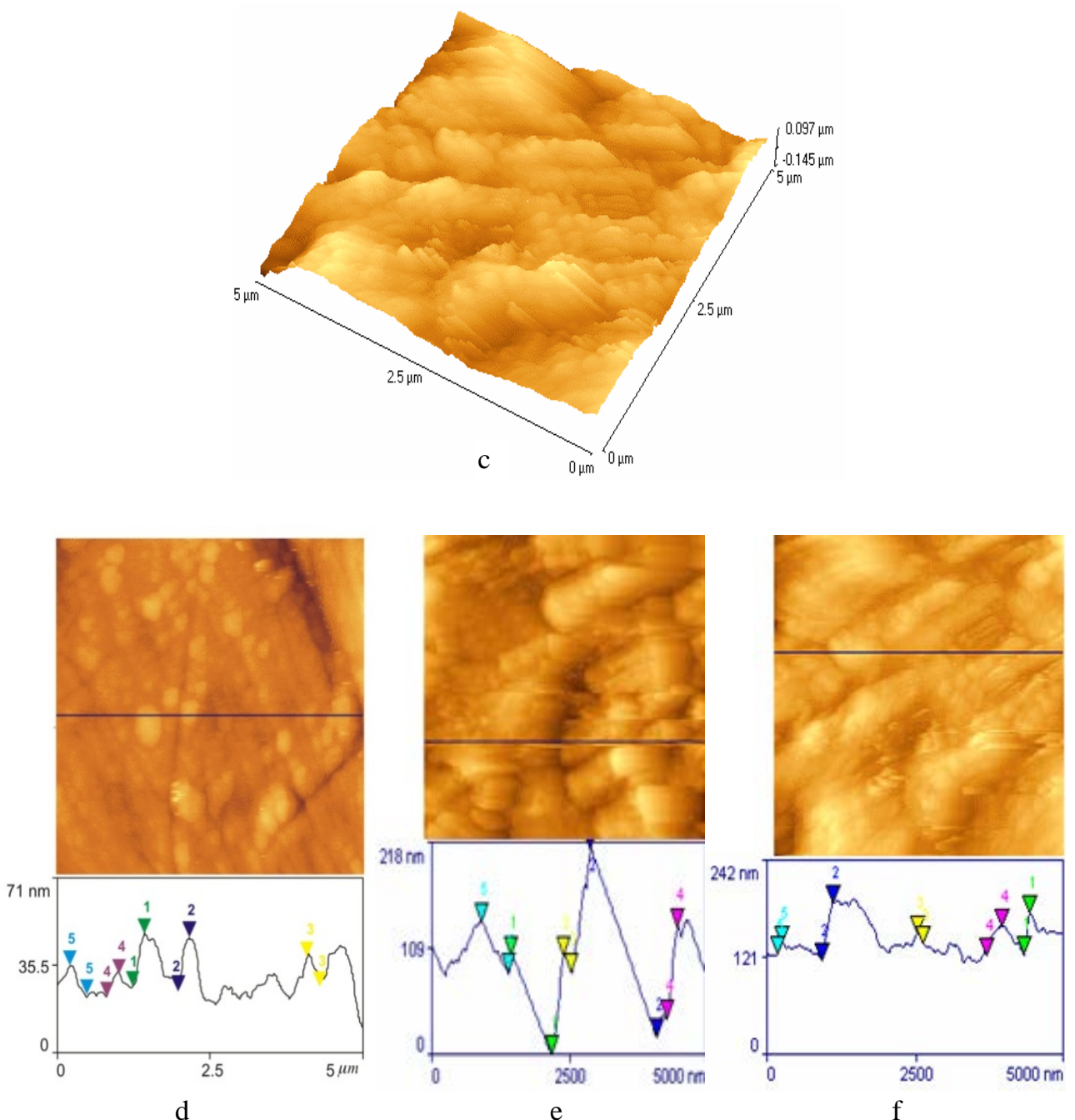

Figure 2 (a,b,c). Three dimensional AFM images of the surface of: a) As polished carbon steel (control); b) carbon steel immersed in sea water (blank); c) carbon steel immersed in sea water containing GA (200 ppm) $+\mathrm{Zn}^{2+}(25 \mathrm{ppm})$; Figure 2 (d,e,f). AFM cross-sectional images of the surface of: d) as polished carbon steel (control); e) carbon steel immersed in dam water (blank); f) carbon steel immersed in sea water containing GA (200 ppm) $+\mathrm{Zn}^{2+}$ (25 ppm)

Root- mean-square roughness, average roughness and peak-to-valley value AFM image analysis was performed to obtain the average roughness, Ra (the average deviation of all points roughness profile from a mean line over the evaluation length), root-mean-square roughness, $\mathrm{Rq}$ (the average of the measured height deviations taken within the evaluation length and measured from the mean line) and the maximum peak-to-valley (P-V) height values (largest single peak-to-valley height in five adjoining sampling heights) ${ }^{28}$. Table 4.is a summary of $(\mathrm{Rq}),(\mathrm{Ra}),(\mathrm{P}-\mathrm{V})$ value for carbon steel surface immersed in different environment. 
Table 4. AFM data for carbon steel surface immersed in inhibited and uninhibited environment.

\begin{tabular}{|c|c|c|c|}
\hline Sample & $\begin{array}{c}\text { RMS (Rq) } \\
\text { Roughness, nm }\end{array}$ & $\begin{array}{c}\text { Average (Ra) } \\
\text { Roughness, nm }\end{array}$ & $\begin{array}{c}\text { Maximum Peak-to- } \\
\text { valley (P-V) } \\
\text { height, nm }\end{array}$ \\
\hline $\begin{array}{c}\text { Polished carbon } \\
\text { steel }\end{array}$ & 4.33 & 3.41 & 35.28 \\
\hline $\begin{array}{l}\text { Carbon steel } \\
\text { immersed in sea } \\
\text { water (blank) }\end{array}$ & 40.2 & 31.0 & 191.9 \\
\hline $\begin{array}{c}\text { Carbon steel } \\
\text { immersed in } 200 \\
\text { ppm of GA- } 25 \mathrm{Zn}^{2+}\end{array}$ & 25.8 & 21.0 & 71.53 \\
\hline
\end{tabular}

Figure 2. (a, d,) displays the surface topography of un-corroded metal surface. The value of $\mathrm{Rq}$, Ra and P-V height for the polished carbon steel surface (reference sample) are $4.3 \mathrm{~nm}$, $3.41 \mathrm{~nm}$ and $35.28 \mathrm{~nm}$ respectively. The slight roughness observed on the polished carbon steel surface is due to atmospheric corrosion. Figure 2 (b, e,) displays the corroded metal surface with few pits in the absence of the inhibitor immersed in sea water. The Rq, Ra, P-V height values for the carbon steel surface are $40.2 \mathrm{~nm}, 31.0 \mathrm{~nm}$ and $191.9 \mathrm{~nm}$ respectively. These data suggests that carbon steel surface immersed in sea water has a greater surface roughness than the polished metal surface, which shows that the unprotected carbon steel surface is rougher and was due to the corrosion of the carbon steel in dam water environment.

Figure 2 (c, f,) displays the steel surface after immersion in sea water containing $200 \mathrm{ppm}$ of GA and 25 ppm of $\mathrm{Zn}^{2+}$. The Rq, Ra, P-V height values for the carbon steel surface are $25.8 \mathrm{~nm}, 21.0 \mathrm{~nm}$ and $71.53 \mathrm{~nm}$ respectively The Rq, Ra, P-V height values are considerably less in the inhibited environment compared to the uninhibited environment. These parameters confirm that the surface is smoother. The smoothness of the surface is due to the formation of a compact protective film of $\mathrm{Fe}^{2+}$-GA complex and $\mathrm{Zn}(\mathrm{OH})_{2}$ on the metal surface thereby inhibiting the corrosion of carbon steel ${ }^{29,30}$.

\section{Conclusion}

The present study leads to the following conclusions. The formulation consisting of $200 \mathrm{ppm}$ of GA and 25 ppm of $\mathrm{Zn}^{2+}$ offers $87 \%$ of inhibition efficiency. A synergistic effect exists between GA- $\mathrm{Zn}^{2+}$ systems. Polarization study reveals that this formulation controls the anodic reaction predominantly. AFM spectra reveal that a protective film is formed on the metal surface.

\section{References}

1. $\quad$ Eddy N O, J Adv Res., 2011, 2, 35-47.

2. $\quad$ Gece G and Bilgiç S, Corros Sci., 2010, 52, 3435-3443.

3. $\quad$ Khaled K F, Corrosion Science, 2010, 52, 3225-3234.

4. Tkalenko D A, Venkatesvaran G, Vishevskaya Yu P, Keny S J, Byk M V and Muthe K, Protection Metals Phy Chem Surfaces, 2010, 46, 609-614.

5. Ahn S, Song H-J, Park J-W, Lee J H, Lee I Y and Jang K-R, Korean J Chem Eng., 2010, 27(5), 1576-1580.

6. Amin M A, Khaled K F, Mohsen Q and Arida H A, Corros Sci., 2010, 52(5), 1684-1695.

7. Ranjana Banerjee R and Nandi M M, Indian J Chem Technol., 2010, 17, 176-180. 
8. Saifi H, Bernard M C, Joiret S, Rahmouni K, Takenouti H and Talhi B, Mater Chem Phys., 2010, 120, 661-669.

9. Mobin M, Parveen $\mathrm{M}$ and Alam Khan M,Portugaliae Electrochemica Acta, 2011, 29(6), 391-403.

10. Ashassi-Sorkhabi H and Asghari E, J Appl Electrochem., 2010, 40(3), 631-637.

11. El-Sherbin E E F, Wahaab S M A and Deyab M, Mat Chem Phys., 2005, 89, 83-191.

12. Talti J D,.Desai M N and Shah N K, Mat Chem Phys., 2005, 93(1), 54-64.

13. Manickavasagam R, Jeya Karthik K, Paramasivam M and Venkatakrishna Iyer S, Anti Corros Methods Mater., 2002, 49, 19-26.

14. Aliev T A, Mat Sci., 2008, 44, 69-74.

15. Spah M, Spah D C, Deshwal B, Lee S, Chae Y-K and Park J W, Corros Sci., 2009, 51, 1293-1298.

16. Aouniti A, Hammouti B, Abed Y and Kertit S, Bull Electrochem., 2001, 17, 13-17.

17. Wranglen G, Chapman \& Hall, London, 1985, 236.

18. Rajendran S, Shanmugapriya S, Rajalakshmi T and Amalraj A J, Corrosion, 2005, 61, 685-692.

19. Wilson Sahayaraj J, John Amalraj A, Susai Rajendran and Vijaya N, E-J Chem., 2012, 9(4), 1746-1752

20. Fu J-J, Li S-N, Wang Y and Liu X-D, J Mater Sci., 2011, 46, 3550-3559.

21. Mary Anbarasi C, Susai Ranjendran, Narayanasamy B and Krishnavani, Asian $J$ Chem., 2012, 24, 5029-5034.

22. Anthony Samy Sahayaraja and Susai Rajendran, J Electrochem Sci., 2012, 2, 91-104.

23. Eddy N O, Ibok U J and Ita BI, J Computational Methods Sci Eng., 2011, 11, 25-43

24. Obot I B and.Obi-Egbedi N O, Corros Sci., 2010, 52, 198-204.

25. Solomon M M, Umoren S A, Udosoro I I and Udoh A P, Corros Sci., 2010, 52, 1317-1325.

26. Johnsirani V, Rajendran S, Shanthi T, Muthumahala T S and Krishnaveni A, Bulgarian Chem Commun., 2012, 44(1), 41-51.

27. Sangeetha M, Rajendran S, Sthiyabama J, Krishnavani A, Shanthy P, Manimaran N and Shamaladevi B, Porthugaliae Electrochimica Acta, 2011, 29(6), 429-444.

28. Ashish Kumar Singh and Quraishi M A, Corros Sci., 2011, 53(4), 1288-1297.

29. Wang B, Du M, Zhang J and Gao C J, Corros Sci., 2011, 53, 353-361.

30. Stout K J, Sullivan P J and McKeown P A, Annals CRIP, 1992, 41(1), 621-624. 